KRZYSZTOF RATAJCZAK

Uniwersytet im. Adama Mickiewicza w Poznaniu e-mail: tangram@amu.edu.pl

\title{
THE PILGRIMAgeS OF THE PIAST DYNASTY IN THE MIDDLE AGES
}

The first from the Piast dynasty who had contact with the relics of the Saints was Mieszko I. His visits to the German shrines, especially in Quedlinburg, however, did not have a religious dimension, but were connected with politics. The fact is that they took place during the great feasts, so the Polish Prince had to participate in religious ceremonies. It is possible, that during such ceremonies the shrines were visible ${ }^{1}$. The son of Mieszko I, Bolesław Chrobry, was kept as a hostage in the Imperial Court ${ }^{2}$ since the age of seven, although in practice he went to the monastery in Magdeburg, where there was a famous school run by master Otryk. Among the students of this school were the sons of

${ }^{1}$ Mieszko arrived at the Hoftag to Quedlinburg for the first time on Easter 973 and again at Easter 984, also in 986. See recently: P. Urbańczyk, Mieszko Pierwszy Tajemniczy, (2012), pp. 341-351.

2 This occurrence was mentioned in the year of 973 by Annales Altahenses maiores, ed. E. v. Oefele, (Monumenta Germaniae Historica. Scriptores Rerum Germanicarum 9, 1868), p. 787. 
the Prince of Libice: Sławnik, Adalbert and Radim Gaudentius ${ }^{3}$. Over the ages, the Piasts participated in several types of pilgrimages. The typology presented in the further part of article is my own, and based mainly on the destination of the pilgrimage.

\section{"AD LOCA SANCTA"}

The destination of this kind of pilgrimage was the tomb of a Saint, or a relic, or a miraculous image ${ }^{4}$. One of the first pilgrim acts in the history of the Piast dynasty was the congress and synod in Gniezno, which took place in connection with the canonization of St. Adalbert in 998 and the establishment of the new Archbishopric by Pope Sylvester II in $999^{5}$. The ceremony was graced by the presence of Emperor Otto III, who came to Gniezno during the pilgrimage ${ }^{6}$. The Polish Prince Bolesław Chrobry greeted the Emperor in the country of Dziadoszanie (lat. Dadosesani) ${ }^{7}$. It is highly likely, although unfortunately not proven

3 G. Labuda, Mieszko Drugi. Król Polski w czasach przełomu 1025-1034, (1994), p. 30 .

4 A. Witkowska OSU, Peregrinatio religiosa w średniowiecznej Europie, in: Peregrinationes. Pielgrzymki w kulturze dawnej Europy, ed. by H. Manikowska, H. Zaremska, (1995), pp. 9-16.

5 Bullarium Poloniae, 1: 1000-1342, ed. et curaverunt I. Sułkowska-Kuraś, S. Kuraś, (1982), no. 2, p. 3.

6 With the extensive literature issues see: K. Maleczyński, W sprawie zjazdu gnieźnieńskiego z roku 1000, "Śląski Kwartalnik Historyczny Sobótka", 21 (1966), pp. 507-540; S. Trawkowski, Pielgrzymka Ottona III do Gniezna. Ze studiów nad dewocja wczesnośredniowieczną, in: Polska w świecie. Szkice z dziejów kultury polskiej, ed. by J. Dowiat, (1972), pp. 107-124; J. Strzelczyk, Otton III, (2000); idem, Zjazd gnieźnieński, (2000); G. Labuda, Zjazd i synod gnieźnieński w roku 1000, "Kwartalnik Historyczny”, 107, 2 (2000), pp. 107-122; H. Ludat, Piastowie i Ottonowie. Wokót zjazdu gnieźnieńskiego, "Zapiski Historyczne”, 65, 2 (2000), pp. 7-30.

7 Thietmari Merseburgensis episcopi Chronicon, ed. by F. Kurze, (Monumenta Germaniae Historica Scriptores rerum Germanicarum in usum scholarum separatim editi 54, 1889), lib. IV, cap. 45, p. 89: "Decursis tunc Milicini terminis huic ad Diedesisi 
by sources, that Bolesław I completed the last part of the journey to the tomb of Saint Adalbert barefoot, alongside Emperor Otto III ${ }^{8}$. Certainly he greeted the emperor at the threshold of the temple, where the martyr's body was buried. The body of Adalbert had been previously bought from the pagans. It is thought that the Polish Prince accompanied Otto's entourage on the way to Aachen, and together with Otto, Bolesław paid tribute to the relics of Emperor Charlemagne on May 19, $1000^{9}$. Over the centuries, Aachen was visited by Prince Louis I of Brzeg (CA. 1313-1398). His pilgrimage took place in the year 1373.

To the ceremony of the translatio of the relics of St. Stanislaus in Kraków on 8 March 1254, organized by Bishop Prandota, on the occasion of Stanislaus' canonization, the following group of Piast Dukes came: Kazimierz of Łęczyca and Kujawy, Przemysł of Great Poland, Siemowit I of Masovia, Władysław of Opole, and Duke of Kraków and Sandomierz, Bolesław Wstydliwy (the Shy ${ }^{10}$. During the ceremony, the Duke of Opole knelt and thanked the Saint for his healing ${ }^{11}$.

Undoubtedly, the canonization of St. Hedwig was a great event for the Piasts. The Dynasty finally had its own Saint, a member of the

paganum primo venienti Bolizlaus - qui maior laus non merito, sed more antique interpretatur - parato in loco, qui Ilua dicitur, suimet hospicio, multum hilaris occurit".

8 The Emperor made the last steps of his journey barefoot: "Videns a longe urbem desideratam nudis pedibus suppliciter advenit et ab episcopo eiusdem Ungero venerabiliter succeptus aecclesiam introducitur et ad Christi gratiam sibi inpetrandam martyris Christi intercessio profusis lacrimis invitatur", Thietmari Merseburgensis episcopi Chronicon, lib. IV, cap. 45, p. 89.

9 Ibidem, lib. IV, cap. 46, 47, pp. 90-91. An idea promoted, among other things in the popular book: S. Bratkowski, Wiosna Europy. Mnisi, królowie i wizjonerzy, (1997), p. 315. There is no evidence for this theory in any sources.

10 Rocznik kapituly poznańskiej 965-1309, ed. by B. Kürbis, (Monumenta Poloniae Historica. Series nova 4, 1962), p. 34. See W. Dominiak, Rola kultu św. Stanisława na Śląsku w polityce zjednoczeniowej książąt opolskich w XIII w., in: Kult św. Stanisława na Śląsku (1253-2003), ed. by A. Pobóg-Lenartowicz, (2004), p. 58.

11 Wincenty z Kielczy, Vita maior sancti Stanislai, in: Średniowieczne żywoty i cuda patronów Polski, transl. J. Pleziowa, ed. by M. Plezia, (1987), p. 298. 
family. The translation of the relics of St. Hedwig to the new Chapel took place on August 25 1269. The ceremony brought together many of the Dukes: "Wlodislaus dux Slezie et Salzburgensis fratres et episcopi vagantes ipsius duces Slesie eiusdem sancte nepotes et plures Polonie duces"12. The Hedwig of Silesia, canonized in 1267, belonged to a family which helped to evangelize the East while fighting with the Mongols, and who supported Rome in its conflict with the Hohenstaufen $^{13}$. Interestingly, the pilgrimages of the Piasts to the tomb of St. Hedwig took place occasionally, and in the case of Władysław Jagiełło and Prince of Legnica and Brzeg Bolesław, it is even difficult to use the term 'pilgrimage', since both of the Princes de facto occupied these lands in $1322^{14}$.

It is worth mentioning briefly the most mysterious pilgrimage of Prince Mieszko III to the shrine of the Ten Thousand Virgins of Cologne, mentioned by Jan Długosz ${ }^{15}$. The visit of the Polish duke to Cologne was, in the intention of Długosz, connected with the foundation of a Cistercian cloister in $\mathrm{Laqd}^{16}$. There is no other evidence for such a pilgrimage, and we can suppose that this story was only the fruit of the imagination of the famous Polish historian from the $15^{\text {th }}$ century.

12 Vita sanctae Hedwigis, ed. by A. Semkowicz, (Monumenta Poloniae Historica 4, 1884), p. 631: "Wlodislaus Slezie dux et Salzburgensis episcopus et fratres ipsius duces Slesie eiusdem sancte nepotes ac plures Polonie duces".

13 M. Goodich, Vita perfecta, the ideal of sainthood in the thirteenth century, (1982), p. 43.

14 H. Manikowska, Ruch pielgrzymkowy na Śląsku w późnym średniowieczu-problemy badawcze, in: Peregrinationes. Pielgrzymki, p. 226.

15 Z. Kozłowska-Budkowa, Repertorium polskich dokumentów doby piastowskiej, 1: do końca XII w., (1937), pp. 45-47.

16 Ioannis Dlugossii Annales seu Cronicae incliti Regni Poloniae. Lib. 5-6, [ed. by S. Budkowa et al.], (1973), p. 34: [anno 1145] "Visitanti siquidem Myeczslao Maioris Polonie duce ecclesiam Aquisgrani et corpora Trium Regum in Colonia, dum a Coloniensibus maximis certatim celebraretur honoribus, hanc Coloniensibus refundit graciam, super qua et privilegium scripsit, ut in vicissitudinem officii sibi a Coloniensibus exhibiti nullus ad duo monasteria prefata nisi sit Coloniensis, possit assumi aut in eisdem tolerari”. 
Returning once again to the sanctuary of St. Adalbert in Gniezno, his cult has been influenced by the dispatch of the relics to Prague by the Czechs during the invasion of Bretislaus in 1038. It seems that the memory of St. Adalbert has been cultivated by the Piasts more by listening to the Vitae of the Saint, than by any pilgrimage to Gniezno Cathedral. Nevertheless, Duke Przemysł I arrived in Gniezno in April 1257 , during the celebrations in honor of St. Adalbert. It is worth mentioning that the Prince's visit could be treated as a pilgrimage for his health; unfortunately he died a little later - on 4 June ${ }^{17}$.

The place sanctified by the cult of the relics of the Holy Cross was the Benedictine Abbey at Łysiec, visited and supported by privileges (in years 1308, 1319, 1351) by Władysław Łokietek and Kazimierz the Great $^{18}$. The donations could be treated as a form of pilgrimage.

Surprisingly, Rome - during the Middle Ages one of the most important destinations of "peregrinationes maiores", was not a popular place to visit for the Polish rulers. It is difficult to find the reason for such an omission, especiallywhen compared with the frequency of bishops from the Gniezno Church province ad limina Apostolorum. According to Stanisław A. Sroka, the only Piast who visited Rome was Queen Elizabeth of Hungary, daughter to the King of Poland, Vladislaus the Short (Władysław Łokietek). She made two pilgrimages: in 1343 to the tombs of the Saints in Rome and in 1357 to the tomb of St. Elizabeth of Hungary at Marburg ${ }^{19}$.

17 Kodeks Dyplomatyczny Wielkopolski, ed. by I. Zakrzewski, 1 (1877), no. 355.

18 Kodeks Dyplomatyczny Małopolski, ed. by F. Piekosiński, 1 (1876), no. 138; ibidem, 2 (1886), no. 576; Kodeks Dyplomatyczny Polski obejmujacy przywileje królów polskich, wielkich książąt litewskich, bulle papiezkie, jako téż wszelkie nadania prywatne mogace posłużyć do wyjaśnienia dziejów wewnętrznych krajowych, dotąd nigdzie nie drukowane, od najdawniejszych czasów aż do roku 1506 wydawany, ed. by J. Bartoszkiewicz, 3 (1858), no. 105. See M. Derwich, Eysogórski ośrodek pielgrzymkowy w Polsce średniowiecznej i nowożytnej. Zarys problematyki, in: Peregrinationes. Pielgrzymki, p. 279.

19 S. A. Sroka, Pielgrzymka królowej Elżbiety Łokietkówny do Rzymu w 1343 roku, "Peregrinus Cracoviensis", 4 (1996), pp. 157-163. 


\section{THE PENITENTIAL PILGRIMAGE}

During the middle ages there were pilgrimages to ask for the mercy and support of the Saint, on someone's behalf in order to serve penance. Penitential pilgrimages were familiar throughout Europe from the $7^{\text {th }}$ century and were made in expiation of sins committed ${ }^{20}$. Sometimes they replaced the banishment imposed by civil law.

The most famous penitential pilgrimage in the history of the dynasty was made by Prince Bolesław III Krzywousty (the Wrymouth). Its background was the blinding of the Prince's half-brother Prince, Zbigniew, for which the ruler was anathematized by Marcin, the Archbishop of Gniezno. The Prince had to make an expiation by pilgrimage to the Abbey of St. Egídia in Samogyvár, the tomb of St. Stephen in Székesfehévár in Hungary, as well as travelling barefoot to Gniezno to the tomb of St. Adalbert on April $61113^{21}$. On his way, he gave alms to the poor as an act of expiation ${ }^{22}$. It seems that the sin for which

20 J. A. Brundage, Medieval Canon Law and the Crusader, (1969), p. 8.

21 According to K. Józefowiczówna, Trzemeszno, klasztor św. Wojciecha, (1978), pp. 20-25, the endpoint of the pilgrimage was Trzemeszno, where the arm of St. Adalbert was kept. In Gniezno, there were no longer any relics of the saint during the years 1038-1127. The relics were taken by the Czechs in year 1038 .

22 Galli Anonymi Cronica et Gesta ducum sive principum polonorum = Anonima tzw. Galla Kronika czyli Dzieje książąt i władców polskich, ed. by K. Maleczyński, (Monumenta Poloniae Historica. Series nova 2, 1952), lib. III, c. 25, pp. 158-159: "Bolezlauus - - iter peregrinacionis ad sanctum Egidium sanctumque regem Stephanum occasione colloquii, paucissimis hoc rescientibus, summa devotione consumavit. - - In pedibus etiam pauperum abluendis, in elemosinis faciendis ita devotus et studiosus per totam viam illius peregrinacionis existebat, quod nullus indigens ab eo misericordiam querens sine misericordia recedebat. - - Bolezlauud sua peregrinacione remeavit - in regnum suum ad sepulchrum usque beati martiris Adalberti - - perduravit". See.: E. Kowalczyk, Pielgrzymki pokutne we wczesnym średniowieczu. Bolesław Krzywousty i Piotr Włostowic, in: Peregrinationes. Pielgrzymki, pp. 157-159; H. Zaremska, Pielgrzymka jako kara za zabójstwo. Europa Środkowa XIII-XV w., in: ibidem, pp. 147-156. About the ritual aspects of the penitence the prince see Z. Dalewski, Rytuat i polityka. Opowieść Galla Anonima o konflikcie Bolesława Krzywoustego ze Zbigniewem, (2005), pp. $7 \mathrm{ff}$. 
Bolesław was punished was that of perjury ${ }^{23}$. All the way the Polish Prince went on foot, sometimes barefoot, and the practices of penance involved washing the feet of the poor, giving alms and expensive gifts of gold and precious fabrics at the passing churches. The most valuable gift was made in Gniezno (or Trzemeszno) - a gold coffin weighing 16 kilograms. The Duke also fasted (from 19 February to 5 April 1113). Written accounts suppose that the Wrymouth made another pilgrimage to St. Gilles in 1129 - in this case, this would have been a thanksgiving pilgrimage for the gift of his life ${ }^{24}$.

The cause of the Polish Dukes' second pilgrimage of penance was the imprisonment of Bishop Thomas of Wrocław by the Silesian Duke Bolesław Rogatka. Well known for his fury, and under the threat of anathema, the Duke of Wrocław promised on December 21258 in the Franciscan monastery in Złotoryja that he would go on the pilgrimage with his knights, wearing appropriate attire and walking barefoot to Wrocław from Złotoryja ${ }^{25}$. Most likely the declaration was not made by the Prince ${ }^{26}$.

\section{"PRO DEFENSIONE TERRE SANCTAE"}

The Polish dynasty joined the crusade movement to the Holy Land relatively late. It is true that all Polish Annals reported the conquest of

23 According to Z. Dalewski, Rytuat i polityka, p. 197. See T. Michałowska, Topika pielgrzyma i pielgrzymki w literaturze polskiego średniowiecza, in: Peregrinationes. Pielgrzymki, pp. 80-82.

24 The hypothesis was based on the story of Jan Długosz in his Annales, II: under the year 1129 and 1130: Ioannis Dlugossii Annales seu Cronicae incliti Regni Poloniae. Lib. 3-4, [ed. by S. Budkowa et al.], (1970), pp. 310-314.

25 Schlesisches Urkundenbuch, bearb. v. W. Irgang, 3: 1251-1266 (1984), no. 278; Z. Dalewski, Ksiażę i biskup. Spór Bolesława Rogatki z biskupem wrocławskim Tomaszem I, "Roczniki Historyczne", 73 (2007), pp. 91 ff.

26 J. Osiński, Bolesław Rogatka. Książę legnicki, dziedzic monarchii Henryków Ślaskich (1220/1225-1278), (2012), p. 263. 
Jerusalem, and perhaps the appeal of Pope Urban II from the year 1095 reached Poland, but there are no traces of activity in this area from the Piast dynasty ${ }^{27}$. The first of the Polish Princes to set off to the East, on a pilgrimage to Palestine in the year 1154 was Henryk of Sandomierz (1130-18.10.1166), the son of Bolesław III Wrymouth and Salomea of Berg, and this fact has been written in many Polish annals ${ }^{28}$. He was accompanied by the appropriate host of knights. Perhaps the Polish Prince resided for some time at the Court of the King of Jerusalem Baldwin III (1143-1163 $)^{29}$. Since, at that time, there was no serious fighting, with the exception of the siege of Damascus, it is highly likely that Henry took the advantage of his stay in the Holy Land and visited numerous shrines and places of pilgrimage. The effect of the pilgrimage to the Holy Land was the foundation of the monastery of the Knights

27 The Pope mentioned Poland: "Sed nunquid vos, Germani, Saxones, Poloni, Bohemi, Hungari, etsi Turcas et Sarracenos intra viscera saevive vestra nondum sentitis, quam a vobis distent, vel iretis, vel fluminibus ignoratis?": $\mathrm{Pa}$ trologia Latina, 151 (1853), k. 581 (available on the Internet: http://books.google.de/ books?id=Ti8G5jOcgcgC\&redir_esc=y, (visited on 15.04.2015). See A. F. Grabski, Polska wobec idei wypraw krzyżowych na przełomie XI i XII wieku. "Duch krzyżowy" Anonima Galla, "Zapiski Historyczne”, 26, 4 (1961), p. 39. See also: K. Olejnik, Wyprawy krzyżowe w średniowiecznych źródłach polskich, in: Rycerstwo Europy środkowo-wschodniej wobec idei krucjat, ed. by W. Peltz, J. Dudek, (2002), pp. 7-15; B. Wyrozumska, Z dziejów polskich pilegrzymek $w$ średniowieczu, "Zeszyty Naukowe Uniwersytetu Jagiellońskiego. Prace Historyczne”, 89 (1989), pp. 79-88; A. Kowalska, Papieskie apele do Polski w sprawie pomocy dla Ziemi Świętej (XII-XIV w.), in: Studia z dziejów średniowiecza i czasów nowożytnych, ed. S. M. Zajączkowski, (2000), pp. 129-143.

28 The relation on the pilgrimage of the Prince: Rocznik kapitulny krakowski, ed. by A. Bielowski, (Monumenta Poloniae Historica 2, 1872), p. 833 and Rocznik Lubiński, (Monumenta Poloniae Historica 2), p. 775; new edition: Monumenta Poloniae Historica. Series nova, 6 (1962), p. 113: "Henricus dux de Sandomir ivit Iherosolimam"; Rocznik Sędziwoja, (Monumenta Poloniae Historica 2), p. 875: Henricus dux Sandomirensis ivit Jerusalem.

29 A. Teterycz-Puzio, Henryk Sandomierski (1126/1133-18 X 1166), (2009), p. 65; M. Gładysz, O zapomnianych polskich krzyżowcach - kilka uwag na marginesie wypraw jerozolimskich księcia Henryka Sandomierskiego i Jaksy z Miechowa, in: Książęta, urzędnicy, złoczyńcy, ed. by B. Śliwiński, (1999), pp. 45-64. 
Hospitallers of Saint John in Zagość ${ }^{30}$. After some years, the Polish Crusader died as a result of wounds suffered during a crusade to Prussia in year 1166.

A little earlier, spending time in Germany after the military conflict with his younger siblings (led by Prince Bolesław Kędzierzawy - the Crisp), Prince Władysław II Wygnaniec (the Exile) took part in a second crusade during the years 1147-1149. His son, Bolesław Wysoki (the Tall), who grew up in Germany in the castle of Altenburg probably also took part in the expedition as a Knight in the Court of Conrad III and, later, Frederick Barbarossa ${ }^{31}$. Probably both of the princes had the opportunity to visit Constantinople with its numerous relics, and shrines of Jerusalem ${ }^{32}$. Bolesław, accompanying Emperor Frederick Barbarossa, participated in his coronation in Rome on 18 June 1155, probably worshiping numerous relics (including the Apostels? ${ }^{33}$. He proved to be an excellent knight participating in the war expeditions of Emperor Frederick I Barbarossa. He became a person of merit during

30 W. Semkowicz, Z. Budkowa, Album Paleographicum. Tabularum I-XXVI textus, (1960), pp. 4-5; M. Smoliński, Geneza joannitów zagojskich w świetle początków zakonu w Niemczech, Czechach i na Morawach oraz związków rodzinnych Kazimierza Sprawiedliwego, in: Władcy, mnisi, rycerze, ed. by B. Śliwiński, (1996), pp. 225-251.

31 The case is confusing, and the reason for this state of affairs is an enigmatic record mentioned by the Greek writer Kinnamos about the King of Lechs, See more: M. Gładysz, W sprawie udziału polskiego księcia w II krucjacie jerozolimskiej (1147-1149), in: Krzyżowcy, kronikarze, dyplomaci, ed. by B. Śliwiński, (1997), pp. 33-52; idem, Zapomniani krzyżowcy. Polska wobec ruchu krucjatowego w XII-XIII wieku, (2002), pp. 54-55. The author sees in that Prince Władysław II the Exile, Bolesław or Henry of Sandomierz, recounting for the latter. In turn M. Dworsatschek, Władysław II Wygnaniec, (2009), p. 175. States that took part in the expedition he or Bolesław the Tall.

32 Ioannis Cinnami epitome rerum ab Joanne et Alexio Comnenis gestarum, ed. by A. Meineke, (Corpus scriptorum historiae Byzantinae, 1836), p. 84. See also: B. Zientara, Bolesław Wysoki. Tułacz, repatriant, malkontent, (2008), p. 42.

33 Zientara, Bolesław Wysoki, p. 44. 
the siege of Milan by imperial troops, and by fighting with the local Knight, well known for his tremendous physical size ${ }^{34}$.

An alternative to the Palestinian crusade was a trip to the North. The crusade to Prussia was included in the crusade movement for the first time, thanks to Bernard of Clairvaux in 1147 in the context of the second crusade, and later they were treated as an alternative to participation in the Middle East crusade. Duke Mieszko III (the Old) took part in the crusade against the Polabí in year 1147, in connection with the second crusade ${ }^{35}$. Prince Bolesław the Crisp, as a senior within the dynasty and after the removal the prince Władysław from the country, took part in the Prussian crusade twice in the years $1147^{36}$ and 1166, without much success. During the crusade, the troops of Duke Casimir mainly attacked the Jaćwings.

Another member of the Piast dynasty who made his crusade vows motivated by the papal bull issued by Innocent III Quia maior in the year 1213 or maybe during the Synod in Wolbórz in year 1215, was Leszek I Biały (the White). This Prince, however, did not keep his vows, explaining to the Pope that the reason for this was his obesity and that in Palestine there was no beer and without this drink he could not live ${ }^{37}$. In return, he took part in expeditions to Prussia between 1222

34 Events that took place in the years 1158-1162, noted by the Kronika polska, ed. by L. Ćwikliński, (Monumenta Poloniae Historica 3, 1961), p. 645.

35 Annales Magdeburgenses, (Monumenta Germaniae Historica. Scriptores 16, 1859), p. 188: Iter fratres ducis Poloniae cum viginti milibus armatorum exiverat. See Barański, Dynastia Piastów w Polsce, p. 228.

36 Annales Magdeburgenses, p. 188: "Cuius [Mesico] etiam frater maior cum infinito exercitu adversus Pruscos crudelissimos barbaros venit, et diutibus ibi moratus est".

37 Gładysz, Zapomniani krzyżowcy, pp. 149-156. Consent to change the crusade was granted by Pope Honorius III in year 1216. See: K. Zielińska-Melkowska, Polskie wyprawy krzyżowe do Prus $w$ drugiej połowie XII $i$ w pierwszej połowie XIII wieku na tle idei krucjatowej, in: Rycerstwo Europy środkowo-wschodniej wobec idei krucjat, pp. 69-89. 
and 1223, and he also visited the Church of the canons of the Holy Sepulchre in Miechów ${ }^{38}$.

The organizer of the Prussian crusades of the Polish Dukes was Henry I Brodaty (the Bearded), whose interest in the activities of the crusades in East Prussia can be dated from the year 1218, when the Duke of Wrocław sent to Prussia, the Czech and the Polish Crusaders under the command of Prince Dypold and the Bishop of Wrocław, Lawrence ${ }^{39}$. In expeditions to Prussia in 1233-1234 his son was also present - Henry II the Pious, "christianissimus princeps Poloniae", who ended his life on the Good Field of Legnica fighting against the Tatars, which we can also treat as a holy war ${ }^{40}$.

In 1217, in the army of the King of Hungary, Andrew, who set off on a crusade to the Holy Land, there were Polish knights led by the Polish Prince (none of the historical sources reveal his name). Among researchers there is no complete consensus as to its identity. Some of them believed that it was Casimir I (1179-1229), Duke of Opole ${ }^{41}$, while others would like to see Prince Władysław of Great Poland in this role ${ }^{42}$.

38 M. Starnawska, Rola polskich zakonów krzyżowych w ruchu pielgrzymkowym, in: Pielgrzymki w kulturze średniowiecznej Europy. Materiały XIII Seminarium Mediewistycznego, ed. by J. Wiesiołowski, (1993), p. 113.

39 Annales Pragenses ed. by. J. Emler, (Fontes Rerum Bohemicarum 2, 1874), p. 283. See also: B. Zientara, Sprawy pruskie w polityce Henryka Brodatego, "Zapiski Historyczne”, 41, 4 (1976), p. 33; idem, Henryk Brodaty i jego czasy, (1975), p. 212.

40 See K. Ratajczak, O okolicznościach odnalezienia zwłok księcia Henryka II Pobożnego na Dobrym Polu pod Legnica (Walstadt), in: Kim jesteś człowieku? Funeralia Lednickie - spotkanie 13, ed. by W. Dzieduszycki, J. Wrzesiński, (2011), pp. 205-213.

41 T. Jurek, Kazimierz I, in: Słownik władców polskich, ed. by J. Dobosz, (1999), p. 210. It is worth mentioning that in his work from 1977 Kazimierz Jasiński published the same opinion, Rodowód Piastów ślaskich, 3: Piastowie opolscy, cieszyńscy i oświęcimscy, (1977), p. 18. See also Gładysz, Zapomniani krzyżowcy, pp. 168-169.

42 K. Jasiński, Genealogia Piastów wielkopolskich. Potomstwo Władysława Odonica, “Kronika Miasta Poznańia”, 2 (1995), p. 38. 
As previously mentioned, the traditional destinations of the Crusades undertaken by Polish Dukes, instead of dangerous and costly trips to the Holy Land, were crusades to Prussia, and slightly later to Lithuania ${ }^{43}$. During the Prussian Crusades, Duke Henry I the Bearded of Wrocław (c. 1168-1238) participated. This Silesian monarch agreed to the settlement of the Teutonic Knights in Poland. He also systematically organized the Crusades to Prussia. His troops attacked Pagans in 1222, and also in July 1223, when Henry arrived in Prussia with a large army, consisting of Silesian knights, troops from Kujawy, and Lesser Poland, as well as reinforcements sent by the Dukes Sviatopolk II and Wartislaw from the Gryfits dynasty. There was a small success in that a number of Prussian captives were baptized ${ }^{44}$. The huge expedition of Piasts to Prussia took place during the winter of 1234 . The numerous troops were led by: Henry I the Bearded, together with his son, Henry the Pious, Konrad I of Masovia and his son Casimir, Prince of Great Poland Władysław Odonic and the dukes from the Gryfici dynasty - Sviatopolk and Sambor ${ }^{45}$. The Idea of the crusade was strongly supported by Pope Gregory IX ${ }^{46}$, and Pope Innocent IV ${ }^{47}$.

The Prussian Crusade, and a little later the Lithuanian Reise (germ. type of crusade) attracted the Piast dynasty to the Teutonic Knights. The ranks of the order, in fact, were familiares participating in the expedition to Lithuania in 1329, the Duke Bolesław III of Brzeg, Henry VI of Wrocław, Władysław of Legnica and Bolko II of Swidnica ${ }^{48}$. This kind

43 E. Christiansen, The Northern Crusades. The Baltic and the Catholic Frontier 1100-1525, (1980); S. Ekdahl, Crusades and Colonization in the Baltic, in: Palgrave Advances in the Crusades, ed. by H. J. Nicholson, (2005), pp. 172-203.

44 Zientara, Sprawy pruskie, p. 35.

45 Barański, Dynastia Piastów w Polsce, p. 332.

46 T. Jasiński, Trzy nie znane oryginalne bulle Grzegorza IX dotyczące misji pruskiej z lat 1232-1234, "Zapiski Historyczne”, 52, 3-4 (1987), pp. 57-68.

47 Preußisches Urkundenbuch. Politische Abtheilung, bearb. v. A. Philippi, A. Seraphin, 1 (1882), no. 154, 163.

48 G. Müller, Die Familiaren des Deutschen Ordens, (1980), p. 57. 
of custom among the Silesian Dukes was instituted by Bolko II, who took part in the expedition of the Crusaders to Lithuania in $1322^{49}$. The participation of Poles in the Teutonic Knights 'Reise' in Lithuania was also visible in the late 1470s and early 1480s, so after the formal adoption of Christianity by the Lithuanians, and after Władysław Jagiello's accession to the throne of the Kingdom of Poland ${ }^{50}$.

The Piasts Dukes also fought with the Pagans under the banners of the Teutonic Knights in their 'Reisen'. During the expedition to Lithuania in year 1322, Duke Bolko II of Ziębice was present. Also Prince Władysław the White of Gniewków took part in the 'Reise' in year $1366^{51}$, who a few years earlier had stayed in the Holy Land and slightly later, in 1372, the Duke of Brzeg, Louis I also took part in the 'Reise'52. It should be remembered that there were 'Reisen' "in laudem Dei et virginis Marie" 53 , and they began on St. Mary's feasts - 2 February, and 15 August $^{54}$.

The Piast dynasty also participated in the crusade movement by joining one of the military orders. The order of Hospitallers of Saint John was particularly popular, brought to Poland by Prince Henry of Sandomierz. The Hospitaller was, among others, Mieszko, son of Casimir II, Duke of Bytom who, thanks to the protection of his sister

49 T. Jurek, Bolko, ks. Ziębicki, in: Słownik władców polskich, ed. by J. Dobosz, (1999), p. 89.

50 See more in: K. Górski, J. Pakulski, Udział Polaków w krzyżackich rejzach na Litwę $w$ latach siedemdziesiatych i osiemdziesiątych XIV stulecia, "Zapiski Historyczne", 52, 3 (1987), p. 41 ff; A. Supruniuk, O wyprawach do Prus rycerzy polskich $i$ wojnie domowej $w$ Koronie w latach 1382-1385, "Zapiski Historyczne”, 65, 2 (2000), pp. 255-260.

51 Kronika Jana z Czarnkowa, translated J. Żerbiłło, (2001), p. 51.

52 J. M. Gruzla, Udział książąt Śląska $w$ rejzach krzyżackich na Litwę w XIV wieku, "Rocznik Elbląski", 18 (2002), pp. 67-95.

53 Wigandi Marburgensis, equitis et fratris ordinis Teutonici Chronicon seu annales, ed. by J. Voight, E. Raczyński, (1842), cap. 130, p. 618 and cap. 132, p. 620.

54 M. Dygo, O kulcie maryjnym w Prusach krzyżackich, "Zapiski Historyczne”, 52, 2 (1987), pp. 5-38. 
Maria, Queen of Hungary in the years 1315-1319 was the prior of the order in Hungary. The Prince Siemowit of Cieszyn was the prior of the Hospitallers in the Czech Kingdom between 1372 and 1390, and the same office was held by Rupert, Duke of Lubin in years $1423-1434^{55}$.

The Teutonic order in year 1416 was joined by Konrad VIII the Younger (d. 1447), the grandson of Konrad II of Oleśnica and Kozielsk ${ }^{56}$. But it should be concluded that more often than not he stayed in Silesia. He served as provincial superior of the dignity of the order in the Czech Kingdom and Moravia.

\section{"AD TERRAM SANCTAM"}

In the $14^{\text {th }}$ century Palestine was an attractive pilgrimage destination for the Piast dynasty. The Duke of Głogów and Żagan Henry V the Iron (d. 1369) in his youth took part in the expedition of Charles IV of Bohemia to Rome, where the king handed him the Knight's belt. From there, he went on an expedition to Palestine with Prince Nicholas of Ziębice and a troop of 20 people. Bolko died on his way back to Hungary in $1358^{57}$. The next journey was a pilgrimage to Jerusalem by Prince Władysław the White of Gniewków (d. 1388). After the end of the pilgrimage and 'Reise' in Prussia, he entered the Cistercian order and he became a monk of the Cistercian Abbey in Citeaux (1366), and then of the Benedictines in Dijon. After 1370 he went to Poland without the permission of the Pope having broken his vows ${ }^{58}$. He undertook

55 M. Starnawska, Zarys dziejów joannitów na ziemiach polskich w średniowieczu, in: Zakon maltański w Polsce, ed. by S. K. Kuczyński, (2000), p. 35.

56 K. Jasiński, Rodowód Piastów śląskich, 2: Piastowie świdniccy, ziębiccy, głogowscy, żagańscy i oleśniccy, (1975), p. 186.

57 H. Manikowska, Jerozolima - Rzym - Compostella. Wielkie pielgrzymowanie u schyłku średniowiecza, (2008), p. 57.

58 The Prince was forced to return to the ranks of the Benedictine, became an Abbot in Pannonhalma, where he stayed until 1379. The Piast died as Prince of Gniewków. 
the pilgrimage in 1361, after the death of his wife. He did this "in the company of many of the nobility" 59 .

Around the year 1402 Duke Louis II of Brzeg set off to Palestine. The Holy Land was one of the destinations of his grand tour including Czech, Hungary, Germany, the Netherlands, Paris and London. It is worth noting that the Piast, during his stay in Palestine, was captured by the Saracens, which undoubtedly must have been an interesting experience for the Silesian ruler ${ }^{60}$. The Duke's travels were dictated by the customs and traditions typical for that time combining the exploration of sacred places with chivalrous adventures, which at times were tiring for his subjects. In 1404, the Principality of Brzeg-Legnica had accumulated a large sum of 4,000 grzywna, this is about 800 kilograms of silver for the redemption of Louis from captivity and the Prince happily returned to Brzeg in the last months of $1405^{61}$. In 1507 the Holy Sepulchre in Jerusalem was also visited by Duke Frederick II of Legnica. He was accompanied by dozens of people from his procession.

George II of Brzeg (b. 1523) at the age of 27 years made an expedition to Palestine and also visited Italy. It seems that the late Middle Ages visit of the Piasts to the Holy Land can be placed more appropriately in the category of tourist pilgrimages, whose aim went beyond a purely religious experience, to collect all sorts of curiosities and visit various attractions ${ }^{62}$.

His fate is told by the Kronika Jana z Czarnkowa, pp. 50-52. See also in W. Mruk, Pielgrzymowanie do Ziemi Świętej w drugiej połowie XIV wieku, (2001), pp. 40, 182.

59 Kronika Jana z Czarnkowa, pp. 51.

60 F. Szafrański, Ludwik II brzesko-legnicki. Feudał śląski z doby późnego średniowiecza, (1972), pp. 46-47.

61 Ibidem, p. 49.

62 About the evolution of pilgrimages in the late Middle Ages, see: Witkowska OSU, Peregrinatio religiosa, pp. 9-16. 


\section{FOUNDATIONS ASSOCIATED WITH MAKING A PILGRIMAGE}

The return from the pilgrimage was for the Dukes a great opportunity to make pious foundations established as a token of gratitude for a safe journey ${ }^{63}$. We have already mentioned the foundation for the Knights of St. John in Nida, made after his return from the Holy Land by Prince Henry of Sandomierz. It could be noticed that those Piasts, who took part in the crusade movement had a tendency to make similar donations to military orders, especially the Hospitallers and Knights Templars ${ }^{64}$. Naturally, this issue cannot be considered without taking into consideration, for example, the political background of the Foundation.

The Foundation for the Hospitallers in Poznań, made between 1187-1193 by Prince Mieszko the Old along with bishop Radwan may be considered in the context of the Crusades ${ }^{65}$. From the Piast dynasty it was Władysław Odonic who gave a village on the Ina river to the Knights of St. John. The donation, because of its geographic location, was administered by the commandry in Stargard ${ }^{66}$. The donation covered 1600s lans (in Latin laneus) of Korytowo, Recz, Żeliszewo, Suliszewo, Lubieniow and Rzecko. Odonic granted a lot of the territory of the Knights Templar - among others. Chwarszczany on the Myśla river along with a thousand fiefs and the German law ${ }^{67}$.

63 H. Manikowska, Princeps fundator. W przedlokacyjnym Wrocławiu. Od Piotra Włostowica do Henryka Brodatego, in: Fundacje i fundatorzy w średniowieczu i epoce nowożytnej, ed. by E. Opaliński, T. Wiślicz, (2000), pp. 37-57.

64 See M. Starnawska, Między Jerozolimą a Łukowem. Zakony krzyżowe na ziemiach polskich w'sedniowieczu, (1999), passim.

65 Kodeks Dyplomatyczny Wielkopolski, no. 29. See M. Smoliński, Joannici w polityce książat polskich i pomorskich od połowy XII do pierwszego ćwierćwiecza XIV wieku, (2008), pp. $91 \mathrm{ff}$.

66 Kodeks Dyplomatyczny Wielkopolski, no. 202; see P. Stróżyk, Dokumenty Władysława Odonica dla zakonu joannitów z 23 maja 1237 roku, "Roczniki Historyczne", 71 (2005), pp. 141-151.

67 Urkunden und Regesten zur Geschichte des Templerordens im Bereich des Bistums 
Finally, it is worth mentioning the foundations resulting from a pilgrimage to St. Gilles per procura by Princess Judita and Władysław Herman, begging for the heir of the throne of Poland ${ }^{68}$. After the birth of Bolesław Krzywousty, Judita and Władysław established the foundation of churches dedicated to St. Egídia in Kcynia, Inowłódź, Krobia and Kłodawa ${ }^{69}$.

As we can observe, there were various motives for undertaking pilgrimages just as there were many forms of pilgrimages. The Piasts, as great lords, were usually accompanied in their journey by larger or smaller retinues of vassals and servicemen. Even during the penitentiary pilgrimage of Duke Bolesław III, bishops and priests also participated.

In addition to the pilgrimage per se, a good opportunity for the Piasts to visit holy places were congresses with the German emperors and kings, which took place in important religious centers like Quedlinburg, Magdeburg, Meissen or Bamberg ${ }^{70}$. Of course, the reason for the congress was political, but it is hard to imagine that the Polish ruler did not enter the sanctuaries, especially that the congresses were held at the same time as important religious holidays.

Cammin und der Kirchenprovinz Gnesen, ed. by W. Irgang, (1987), no. 6. See: E. Rymar, Komandoria chwarszczańska templariuszy i joannitów (1232-1540), "Nadwarciański Rocznik Historyczno-Archiwalny”, 9 (2002), p. 11 ff. P. Hope, Kwestia sprowadzenia templariuszy do Polski. Rozwój uposażenia zakonu w Wielkopolsce, "Poznański Rocznik Archiwalno-Historyczny”, 1 (1993), pp. 15-40; M. Starnawska, Zarys dziejów joannitów na ziemiach polskich w średniowieczu, in: Zakon maltański $w$ Polsce, ed. by S. K. Kuczyński, (2000), pp. 11 ff. Here also the older literature. According to Christian Gahlbeck Odonic only confirmed the donation made by the duke Henry the Bearded, Zisterzienser und Zisterzienserinnen in der Neumark, (2002), p. 101.

68 Galli Anonymi Cronica, lib. I, cap. 30-31 and lib. II, cap.1.

69 S. Bober, Kult św. Idziego w Polsce w świetle wezwań kościołów, (2004), pp. 65 ff.

70 L. Wetesko, Piastowie i ich państwo w łacińskiej Europie. Studia z dziejów kultury politycznej X i XI wieku, (2013), pp. $90 \mathrm{ff}$. 


\section{PIELGRZYMKI KSIĄŻĄT Z DYNASTII PIASTÓW W ŚREDNIOWIECZU}

\section{(STRESZCZENIE)}

Celem artykułu jest omówienie różnych aspektów i typów pielgrzymek królów i książąt $\mathrm{z}$ dynastii piastowskiej w średniowieczu. Analizie poddane zostały pielgrzymki pokutne, pielgrzymki „ad Sanctos”, ,ad locam sanctam”, peregrynacje do Ziemi Świętej, udział władców polskich w krucjatach i w rejzach krzyżackich na Litwę oraz Żmudź. Omówione zostały także skutki udziału Piastów w ruchu pielgrzymkowym, między innymi nadania dla różnych instytucji kościelnych.

\section{WALLFAHRTEN VON FÜRSTEN AUS DER PIASTEN-DYNASTIE IM MITTELALTER}

(ZUSAMMENFASSUNG)

Das Ziel des Aufsatzes ist die Besprechung verschiedener Aspekte und Arten von Wallfahrten von Königen und Fürsten aus der Piasten-Dynastie im Mittelalter. Es werden die Bußgänge, Wallfahrten , ad Sanctos“, ,ad locam sanctam“, Wallfahrten ins Heilige Land, Teilnahme der polnischen Herrscher an den Kreuzzügen und Preußenreisen des Deutschen Ordens nach Litauen und Samogitien analysiert. Diskutiert werden auch die Auswirkungen der Wallfahrten der Piasten auf die allgemeine Wallfahrtsbewegung, unter anderem die Schenkungen an verschiedene kirchliche Institutionen. 


\section{PILGRIMAGES OF PRINCES FROM THE PIAST DYNASTY IN THE MIDDLE AGES}

\section{(SUMMARY)}

The aim of the article is to discuss various aspects and types of pilgrimages of kings and princes from the Piast dynasty in the Middle Ages. The analysis embraces penitentiary pilgrimages, pilgrimages "ad Sanctos", "ad locam sanctam", peregrinations to the Holy Land, the participation of Polish monarchs in Teutonic crusades to Lithuania and Samogitia. The article also addresses the effects of the participation of the Piasts in pilgrimages such as foundations for various church institutions.

Translated by Agnieszka Chabros

\section{Słowa kluczowe / Schlagworte / Keywords}

- Pielgrzymki; Piastowie; średniowiecze

- Wallfahrten; Piasten; Mittelalter

- Pilgrimages; Piast dynasty; Middle Ages

\section{BIBLIOGRAFIA / BIBLIOGRAFIE / BIBLIOGRAPHY}

\section{ŹRÓDłA DRUKOWANE / GEDRUCKTE QUELLEN / PRINTED SOURCES}

Annales Altahenses maiores, ed. E. v. Oefele, (Monumenta Germaniae Historica. Scriptores Rerum Germanicarum 9, 1868).

Annales Magdeburgenses, (Monumenta Germaniae Historica. Scriptores 16, 1859), pp. 105-196.

Annales Pragenses, ed. by. J. Emler, (Fontes Rerum Bohemicarum 2, 1874), pp.376-380. Bullarium Poloniae, 1: 1000-1342, ed. et curaverunt I. Sułkowska-Kuraś, S. Kuraś, (1982).

Galli Anonymi Cronica et Gesta ducum sive principum polonorum = Anonima tzw. 
Galla Kronika czyli Dzieje książąt i władców polskich, ed. by K. Maleczyński, (Monumenta Poloniae Historica. Series nova 2, 1952).

Ioannis Cinnami epitome rerum ab Joanne et Alexio Comnenis gestarum, ed. by A. Meineke, (Corpus scriptorum historiae Byzantinae, 1836).

Ioannis Dlugossii Annales seu Cronicae incliti Regni Poloniae. Lib. 3-4 and 5-6, [ed. by S. Budkowa et al.], (1970, 1973).

Kodeks Dyplomatyczny Małopolski, ed. by F. Piekosiński, 1-2 (1876, 1886).

Kodeks Dyplomatyczny Polski obejmujący przywileje królów polskich, wielkich książą litewskich, bulle papiezkie, jako téż wszelkie nadania prywatne mogące postużyć do wyjaśnienia dziejów wewnętrznych krajowych, dotąd nigdzie nie drukowane, od najdawniejszych czasów aż do roku 1506 wydawany, ed. J. Bartoszkiewicz, 3 (1858).

Kodeks Dyplomatyczny Wielkopolski, ed. I. Zakrzewski, 1 (1877).

Kronika Jana z Czarnkowa, translated J. Żerbiłło, (2001).

Kronika polska, ed. L. Ćwikliński, (Monumenta Poloniae Historica 3, 1961), pp. 578-656.

Preußisches Urkundenbuch. Politische Abtheilung, bearb. v. A. Philippi, A. Seraphin, 1 (1882).

Rocznik kapitulny krakowski, (Monumenta Poloniae Historica 2, 1872), pp. 827-871. Rocznik kapituły poznańskiej 965-1309, ed. by B. Kürbis, (Monumenta Poloniae Historica. Series nova, 6 (1962), pp. 21-78.

Rocznik Lubiński, (Monumenta Poloniae Historica 2, 1868 and Monumenta Poloniae Historica. Series nova, 6, 1962).

Rocznik Sędziwoja, (Monumenta Poloniae Historica 2, 1868), pp. 871-879.

Schlesisches Urkundenbuch, bearb. v. W. Irgang, 3: 1251-1266 (1984).

Thietmari Merseburgensis episcopi Chronicon, ed. by F. Kurze, (Monumenta Germaniae Historica, Scriptores rerum Germanicarum in usum scholarum separatim editi 54, 1889).

Urkunden und Regesten zur Geschichte des Templerordens im Bereich des Bistums Cammin und der Kirchenprovinz Gnesen, ed. by W. Irgang, (1987).

Vita sanctae Hedwigis, ed. by A. Semkowicz (Monumenta Poloniae Historica 4, 1884), pp. 501-655.

Wigandi Marburgensis, equitis et fratris ordinis Teutonici Chronicon seu annales, ed. by J. Voight, E. Raczyński, (1842).

Wincenty z Kielczy, Vita maior sancti Stanislai, in: Średniowieczne żywoty i cuda patronów Polski, transl. J. Pleziowa, ed. by M. Plezia, (1987), pp. 235-344. 


\section{LITERATURA / LITERATUR / LITERATURE}

Bober S., Kult św. Idziego w Polsce w świetle wezwań kościołów, (2004).

Brundage J. A., Medieval Canon Law and the Crusader, (1969).

Christiansen E., The Northern Crusades. The Baltic and the Catholic Frontier 1100-1525, (1980).

Dalewski Z., Książę i biskup. Spór Bolesława Rogatki z biskupem wrocławskim Tomaszem I, "Roczniki Historyczne", 73 (2007), pp. 83-106.

Dalewski Z., Rytuał i polityka. Opowieść Galla Anonima o konflikcie Bolesława Krzywoustego ze Zbigniewem, (2005).

Derwich M., Łysogórki ośrodek pielgrzymkowy w Polsce średniowiecznej i nowożytnej. Zarys problematyki, in: Peregrinationes. Pielgrzymki w kulturze dawnej Europy, ed. by by H. Manikowska, H. Zaremska, (1995), pp. 277-287.

Dominiak W., Rola kultuśw. Stanisława na Śląsku w polityce zjednoczeniowej książąt opolskich w XIII w., in: Kult św. Stanisława na Śląsku (1253-2003), ed. by A. Pobóg-Lenartowicz, (2004), pp. 61-71.

Dworsatschek M., Władysław II Wygnaniec, (2009).

Dygo M., O kulcie maryjnym w Prusach krzyżackich, "Zapiski Historyczne", 52, 2 (1987), pp. 5-38.

Ekdahl S., Crusades and Colonization in the Baltic, in: Palgrave Advances in the Crusades, ed. by H. J. Nicholson, (2005), pp. 172-203.

Gahlbeck Ch., Zisterzienser und Zisterzienserinnen in der Neumark, (2002).

Gładysz M., O zapomnianych polskich krzyżowcach - kilka uwag na marginesie wypraw jerozolimskich księcia Henryka Sandomierskiego i Jaksy z Miechowa, in: Książęta, urzędnicy, złoczyńcy, ed. by B. Śliwiński, (1999), pp. 45-64.

Gładysz M., W sprawie udziału polskiego księcia w II krucjacie jerozolimskiej (1147-1149), in: Krzyżowcy, kronikarze, dyplomaci, ed. by B. Śliwiński, (1997), pp. 33-52.

Gładysz M., Zapomniani krzyżowcy. Polska wobec ruchu krucjatowego w XII-XIII wieku, (2002).

Goodich M., Vita perfecta, the ideal of sainthood in the thirteenth century, (1982).

Górski K., Pakulski J., Udział Polaków w krzyżackich rejzach na Litwe w latach siedemdziesiatych i osiemdziesiatych XIV stulecia, "Zapiski Historyczne”, 52, 3 (1987), pp. 39-58.

Grabski A.F., Polska wobec idei wypraw krzyżowych na przełomie XI i XII wieku. "Duch krzyżowy” Anonima Galla, "Zapiski Historyczne”, 26, 4 (1961), pp. 37-63.

Gruzla J.M., Udział książą Śląska $w$ rejzach krzyżackich na Litwę w XIV wieku, "Rocznik Elbląski", 18 (2002), pp. 67-95.

Hope P., Kwestia sprowadzenia templariuszy do Polski. Rozwój uposażenia zakonu 
w Wielkopolsce, "Poznański Rocznik Archiwalno-Historyczny”, 1 (1993), pp. 15-40.

Jasiński K., Genealogia Piastów wielkopolskich. Potomstwo Władysława Odonica, "Kronika Miasta Poznańia”, 2 (1995), pp. 34-66.

Jasiński K., Rodowód Piastów śląskich, 2: Piastowie świdniccy, ziębiccy, głogowscy, żagańscy i oleśniccy, (1975).

Jasiński K., Rodowód Piastów śląskich, 3: Piastowie opolscy, cieszyńscy i oświęcimscy (1977).

Jasiński T., Trzy nie znane oryginalne bulle Grzegorza IX dotyczace misji pruskiej z lat 1232-1234, "Zapiski Historyczne", 52, 3-4 (1987), pp. 57-68.

Józefowiczówna K., Trzemeszno, klasztor św. Wojciecha, (1978).

Jurek T., Bolko, ks. Ziębicki, in: Słownik władców polskich, ed. by J. Dobosz, (1999), p. 89.

Jurek T., Kazimierz I, in: Słownik władców polskich, ed. by J. Dobosz, (1999), p. 210.

Kowalczyk E., Pielgrzymki pokutne we wczesnym średniowieczu: Bolesław Krzywousty

i Piotr Włostowic, in: Peregrinationes. Pielgrzymki w kulturze dawnej Europy, ed.

by H. Manikowska, H. Zaremska, (1995), pp. 157-159.

Kowalska A., Papieskie apele do Polski w sprawie pomocy dla Ziemi Świętej (XII-XIV w.), in: Studia $z$ dziejów średniowiecza i czasów nowożytnych, ed. S. M. Zajączkowski, (2000), pp. 129-143.

Kozłowska-Budkowa Z., Repertorium polskich dokumentów doby piastowskiej, 1: do końca XII w., (1937).

Labuda G., Mieszko Drugi. Król Polski w czasach przełomu 1025-1034, (1994).

Labuda G., Zjazd i synod gnieźnieński w roku 1000, "Kwartalnik Historyczny”, 107, 2 (2000), pp. 107-122.

Ludat H., Piastowie i Ottonowie. Wokó zjazdu gnieźnieńskiego, "Zapiski Historyczne”, 65, 2 (2000), pp. 7-30.

Maleczyński K., W sprawie zjazdu gnieźnieńskiego z roku 1000, "Śląski Kwartalnik Historyczny Sobótka”, 21 (1966), pp. 507-540.

Manikowska H., Jerozolima - Rzym - Compostella. Wielkie pielgrzymowanie u schytku średniowiecza, (2008).

Manikowska H., Princeps fundator. W przedlokacyjnym Wrocławiu. Od Piotra Włostowica do Henryka Brodatego, in: Fundacje i fundatorzy w średniowieczu i epoce nowożytnej, ed. by E. Opaliński, T. Wiślicz, (2000), pp. 37-57.

Manikowska H., Ruch pielgrzymkowy na Śląsku w późnym średniowieczu - problemy badawcze, in: Peregrinationes. Pielgrzymki w kulturze dawnej Europy, ed. by H. Manikowska, H. Zaremska, (1995), pp. 225-241.

Michałowska T., Topika pielgrzyma i pielgrzymki w literaturze polskiego średniowiecza, 
in: Peregrinationes. Pielgrzymki w kulturze dawnej Europy, ed. by H. Manikowska, H. Zaremska, (1995), pp. 72-85.

Mruk W., Pielgrzymowanie do Ziemi Świętej w drugiej połowie XIV wieku, (2001).

Müller G., Die Familiaren des Deutschen Ordens, (1980).

Olejnik K., Wyprawy krzyżowe w średniowiecznych źródłach polskich, in: Rycerstwo Europy środkowo-wschodniej wobec idei krucjat, ed. W. Peltz, J. Dudek, (2002), pp. $7-15$.

Osiński J., Bolesław Rogatka. Książę legnicki, dziedzic monarchii Henryków Ślaskich (1220/1225-1278), (2012).

Ratajczak K., O okolicznościach odnalezienia zwłok księcia Henryka II Pobożnego na Dobrym Polu pod Legnica (Walstadt), in: Kim jesteś człowieku? Funeralia Lednickie - spotkanie 13, ed. by W. Dzieduszycki, J. Wrzesiński, (2011), pp. 205-213.

Rymar E., Komandoria chwarszczańska templariuszy i joannitów (1232-1540), "Nadwarciański Rocznik Historyczno-Archiwalny", 9 (2002), pp. 11-36.

Semkowicz W., Budkowa Z., Album Paleographicum. Tabularum I-XXVI textus, (1960).

Smoliński M., Geneza joannitów zagojskich w świetle początków zakonu w Niemczech, Czechach i na Morawach oraz zwiazków rodzinnych Kazimierza Sprawiedliwego, in: Władcy, mnisi, rycerze, ed. by B. Śliwiński, (1996), pp. 225-251.

Smoliński M., Joannici w polityce książąt polskich i pomorskich od połowy XII do pierwszego ćwierćwiecza XIV wieku, (2008).

Sroka S. A., Pielgrzymka królowej Elżbiety Łokietkówny do Rzymu w 1343 roku, "Peregrinus Cracoviensis", 4 (1996), pp. 157-163.

Starnawska M., Rola polskich zakonów krzyżowych w ruchu pielgrzymkowym, in: Pielgrzymki w kulturze średniowiecznej Europy. Materiały XIII Seminarium Mediewistycznego, ed. by J. Wiesiołowski, (1993), pp. 109-115.

Starnawska M., Między Jerozolima a Łukowem. Zakony krzyżowe na ziemiach polskich w średniowieczu, (1999).

Starnawska M., Zarys dziejów joannitów na ziemiach polskich $w$ średniowieczu, in: Zakon maltański w Polsce, ed. by S. K. Kuczyński, (2000), pp. 11-37.

Stróżyk P., Dokumenty Władysława Odonica dla zakonu joannitów z 23 maja 1237 roku, "Roczniki Historyczne", 71 (2005), pp. 137-154.

Strzelczyk J., Otton III, (2000).

Strzelczyk J., Zjazd gnieźnieński, (2000).

Supruniuk A., O wyprawach do Prus rycerzy polskich $i$ wojnie domowej $w$ Koronie w latach 1382-1385, "Zapiski Historyczne", 65, 2 (2000), pp. 255-260.

Szafrański F., Ludwik II brzesko-legnicki. Feudał śląski z doby późnego średniowiecza, (1972) 
Teterycz-Puzio A., Henryk Sandomierski (1126/1133-18 X 1166), (2009).

Trawkowski S., Pielgrzymka Ottona III do Gniezna. Ze studiów nad dewocja wczesnośredniowieczna, in: Polska w świecie. Szkice z dziejów kultury polskiej, ed. by J. Dowiat, (1972), p. 107-124.

Urbańczyk P., Mieszko Pierwszy Tajemniczy, (2012).

Wetesko L., Piastowie i ich państwo w łacińskiej Europie. Studia z dziejów kultury politycznej X i XI wieku, (2013).

Witkowska A. OSU, Peregrinatio religiosa $w$ średniowiecznej Europie, in: Peregrinationes. Pielgrzymki w kulturze dawnej Europy, ed. by H. Manikowska, H. Zaremska, (1995), pp. 9-16.

Wyrozumska B., Z dziejów polskich pilegrzymek w średniowieczu, "Zeszyty Naukowe Uniwersytetu Jagiellońskiego. Prace Historyczne”, 89 (1989), pp. 79-88.

Zaremska H., Pielgrzymka jako kara za zabójstwo: Europa Środkowa XIII-XV w., in: Peregrinationes. Pielgrzymki w kulturze dawnej Europy, ed. by H. Manikowska, H. Zaremska, (1995), pp. 147-156.

Zielińska-Melkowska K., Polskie wyprawy krzyżowe do Prus w drugiej połowie XII i w pierwszej połowie XIII wieku na tle idei krucjatowej, in: Rycerstwo Europy środkowo-wschodniej wobec idei krucjat, ed. W. Pelz, J. Dudek, (2002), pp. 69-89.

Zientara B., Bolesław Wysoki. Tułacz, repatriant, malkontent, (2008).

Zientara B., Henryk Brodaty i jego czasy, (1975).

Zientara B., Sprawy pruskie w polityce Henryka Brodatego, "Zapiski Historyczne”, 41, 4 (1976), pp. 27-42. 